\title{
Positive Self-Talk untuk Mengurangi Tingkat Kecemasan Pada Lanjut Usia Dengan Hipertensi
}

(Positive Self-Talk to Reduce Anxiety Levels in Elderly with Hypertension)

\author{
Harisma Fakhrun Nisa'*, Dessy Pranungsari \\ Universitas Ahmad Dahlan, Yogyakarta, Indonesia \\ *harisma.fnisa@gmail.com
}

\begin{abstract}
Abstrak
Penelitian ini bertujuan untuk mengetahui efektivitas teknik positive self-talk sebagai strategi dalam mengurangi kecemasan yang dialami orang lanjut usia penderita hipertensi. Partisipan dalam penelitian ini berjumlah 8 orang yang merupakan orang lanjut usia penderita hipertensi dan memiliki skor kecemasan berat yaitu $>27$ berdasarkan Hamilton Anxiety Rating Scale (HARS). Penelitian ini menggunakan desain eksperimental dengan re-treatment (one group pretest and posttest design). Analisis data menggunakan uji statistic non parametric Wilcoxon untuk melihat perbedaan pretest dan posttest dalam menentukan hasil intervensi. Hasil menunjukkan bahwa terjadi penurunan skor tingkat kecemasan yang dialami oleh 8 partisipan, di mana skor kecemasan berada pada kategori sedang. Hasil analisis data menunjukkan bahwa nilai $Z=-2,536$ dengan signifikansi $p=0,011(p<0,05)$. Artinya, ada perbedaan yang signifikan antara tingkat kecemasan yang dialami partisipan sebelum dan sesudah proses intervensi. Dengan demikian, partisipan mampu mengubah pemikiran negatif yang irrasional, menjadi pemikiran yang lebih positif.

Kata kunci: hipertensi, kecemasan, orang lanjut usia, positive self-talk
\end{abstract}

\begin{abstract}
This research aimed to determine the effectiveness of positive self-talk technique as a strategy to reduce anxiety in elderly with hypertension. The participants in this study were 8 elderly having hypertension and severe anxiety symptoms which were indicated by Hamilton Anxiety Rating Scale (HARS) score $>27$. This research is a experimental study with a re-treatment design treatment (one group pretest and posttest design). The results showed that anxiety level score of the participants had decreased and were in the medium category at the end of the experiment. Data analysis method used were Wilcoxon nonparametric statistical test to examine the differences between pretest and posttest in determining the result of the intervention. The results showed a significant difference $(Z=-$ $2.536, p=0.011)$. Therefore, participants were able to change irrational negative thoughts into more positive thoughts.
\end{abstract}

Keywords: anxiety, elderly people, hypertension, positive self-talk.

\section{PENDAHULUAN}

Lanjut usia (lansia) adalah periode penutup dalam rentang hidup seseorang, yaitu suatu periode di mana seseorang telah beranjak jauh dari periode terdahulu yang lebih menyenangkan atau beranjak dari waktu yang penuh manfaat. Menurut Santrock (2012) batasan usia lanjut dibagi menjadi dua, yaitu usia lanjut (the young/old age) yakni usia 65-75 
tahun dan usia sangat tua (the old old/late old age) yakni usia 75 tahun ke atas. Lansia berdasarkan usia kronologis (biologis) digolongkan menjadi 4 kelompok, yaitu usia pertengahan (45-59 tahun), lanjut usia (60-74 tahun), lanjut usia tua (75-90 tahun) dan usia sangat tua (di atas 90 tahun) (Hurlock, 2012). Sedangkan menurut World Health Organization, usia 65 tahun ditetapkan sebagai usia yang menunjukkan proses penuaan yang berlangsung secara nyata dan disebut lanjut usia.

Lansia di Indonesia akhir-akhir ini semakin banyak mendapatkan perhatian karena faktanya bahwa peningkatan penduduk berusia 60 tahun ke atas cukup signifikan. Hal tersebut berdasarkan data Biro Pusat Statistik (BPS; 2020), yang memaparkan bahwa dari 217 juta jiwa penduduk Indonesia, tercatat 17,3 juta atau hampir $8 \%$ di antaranya adalah penduduk yang berusia 60 tahun ke atas. Hal ini menunjukkan adanya kenaikan dua kali lipat dalam dua dekade.

Prevalensi hipertensi di Indonesia berkisar 30\% dengan insiden komplikasi penyakit kardiovaskular lebih banyak pada perempuan (52\%) dibandingkan laki-laki (48\%). Data dari Riset Kesehatan Dasar (2018) juga menyebutkan hipertensi sebagai penyebab kematian nomor 3 setelah stroke dan tuberkulosis, jumlahnya mencapai $6,8 \%$ dari proporsi penyebab kematian pada semua umur di Indonesia. Kepala Bidang Perlindungan dan Jaminan Sosial Dinas Sosial Kota Yogyakarta menyatakan bahwa saat ini jumlah lansia di Kota Yogyakarta mencapai 13\% dari jumlah penduduk secara keseluruhan yaitu pada angka 45.000 lansia (Riset Kesehatan Dasar, 2018).

Kemunduran segi fisik yang dialami lansia salah satunya oleh penyakit yang dapat disebabkan karena gaya hidup dan pola makan yang kurang tepat. Salah satu jenis gangguan kesehatan yang dapat terjadi pada lansia adalah hipertensi. Penyakit hipertensi menempati urutan pertama dalam masalah kesehatan bagi lansia. Hipertensi merupakan sebuah gangguan kesehatan di mana seseorang mengalami peningkatan tekanan darah, sehingga orang tersebut bisa mengalami serangan jantung ataupun stroke (Sari, Margiyati, \& Rahmanti, 2020).
Hipertensi dikategorikan sebagai the silent disease karena penderita tidak mengetahui dirinya mengidap hipertensi sebelum memeriksakan tekanan darahnya. Di Indonesia, seseorang dikatakan menderita hipertensi jika tekanan darahnya sama dengan atau lebih dari 140/90 mmHg (Girsang, 2013). Mengabaikan hipertensi sama saja dengan membiarkan jantung bekerja lebih keras, sehingga peluang terkena penyakit jantung kongestif 6 kali lebih besar dan 3 kali lebih besar terkena serangan jantung (Imelda, Sjaaf, \& Puspita, 2020).

Dampak jangka pendek dan jangka panjang yang ditimbulkan hipertensi terbilang cukup parah, sehingga membutuhkan penanggulangan jangka panjang yang menyeluruh dan terpadu. Hal ini menjadikan hipertensi sebagai penyakit yang mendapat perhatian dari semua kalangan masyarakat. Faktor terbesar yang mempengaruhi hipertensi adalah usia karena hipertensi identik dengan peningkatan usia. Lansia cenderung terkena hipertensi dibandingkan dengan orang yang lebih muda, meski tidak memungkiri bahwa ada beberapa orang usia muda yang menderita hipertensi juga (Sari, Margiyati, \& Rahmanti, 2020).

Menurut WHO (World Health Organization), pada tahun 2019, hipertensi menyerang 22\% penduduk dunia. Prevalensi kejadian hipertensi sebesar $34,1 \%$, dan angka tersebut terus meningkat tiap tahunnya berdasarkan hasil pengukuran tekanan darah pada masyarakat Indonesia. Prevalensi hipertensi mengalami peningkatan yang signifikan pada orang dengan usia 60 tahun ke atas. Hipertensi pada umumnya tidak dapat sembuh dan bergantung pada obat seumur hidup, dengan demikian para penderita hipertensi selalu dibayang-bayangi dengan penyakit seumur hidup yang mengakibatkan keadaan yang berbahaya sewaktu-waktu dan dapat mengakibatkan kematian (Riset Kesehatan Dasar, 2018).

Terdapat beberapa faktor yang dapat mempengaruhi hipertensi, namun secara garis besar dapat digolongkan menjadi dua faktor, yaitu faktor yang dapat dikontrol dan faktor yang tidak dapat dikontrol. Faktor yang tidak dapat di kontrol, di antaranya adalah genetik, usia, jenis kelamin, dan 
etnis. Kemudian faktor yang dapat dikontrol meliputi obesitas, aktivitas fisik, kebiasaan merokok, konsumsi alkohol, asupan garam, kafein, tinggi kolesterol, dan kecemasan (Uswandari, 2017).

Melihat fenomena hipertensi yang sangat kompleks serta rumit yang banyak dialami oleh Lansia, segala bentuk daya dan upaya dalam penanganan hipertensi harus dilakukan dengan optimal, tepat, dan efisien, agar kondisi tubuh lansia yang mengalami hipertensi dapat kembali membaik dan stabil. Hanya saja, biasanya faktor-faktor psikologis sangat berpengaruh terhadap proses penanganan masalah hipertensi, di mana dengan keterbatasan fisik yang dialami oleh lansia, terkadang lansia mengalami kecemasan karena berbagai penyakit yang diderita tidak kunjung sembuh bahkan semakin memburuk. Hal ini membuat harapan untuk sembuh menjadi sangat tipis, terlebih lagi rasa pesimistis dari para penderita hipertensi menjadikan penderita merasa cemas dan menyerah dengan keadaan (Ridwan, Widodo, \& Widiani, 2017).

Cemas merupakan hal wajar bagi individu, namun kecemasan tidak boleh dibiarkan karena lambat laun dapat menjadi neurosis cemas melalui mekanisme yang diawali dengan kecemasan akut yang berkembang menjadi kecemasan menahun akibat represi dan konflik yang tidak disadari. Adanya stres pencetus dapat menyebabkan penurunan daya tahan dan mekanisme untuk mengatasinya sehingga mengakibatkan neurosis cemas (Maramis, 2016). Risiko ini akan semakin tinggi ketika terjadi pada lansia. Apabila kecemasan ini tidak diatasi dengan baik, maka akan memberi dampak negatif yaitu Lansia bisa menarik diri, membisu, hiperaktif, mengumpat, bicara berlebihan, menyerang dengan kata-kata bahkan dengan fisik, berkhayal, serta menangis (Brunner \& Suddarth, 2013).

Faktor-faktor risiko tingkat kecemasan, yaitu salah satunya jenis kelamin, di mana wanita lebih rentan dibandingkan laki-laki (Sundeen \& Stuart, 2015). Kecemasan yang dialami oleh wanita, kemungkinan disebabkan karena wanita lebih mempunyai kepribadian yang cenderung lebih labil, peran hormon yang dapat mempengaruhi kondisi emosi sehingga mudah meledak, mudah cemas dan mudah curiga (Kaplan \& Sadock, 2010).

Kondisi emosi seperti yang disebutkan di atas dapat juga ditemui pada penderita hipertensi. Penderita hipertensi yang mengalami peningkatan tekanan darah tinggi terjadi ketika penderita mengalami atau dihadapkan pada situasi yang membuat penderita merasa tertekan, stres atau mengalami kecemasan. Hal ini senada dengan penelitian yang dilakukan Uswandari (2017) yang menyatakan bahwa terdapat hubungan positif yang signifikan antara kecemasan dengan kejadian hipertensi pada lansia.

Individu yang mengalami kecemasan, akan mengeluarkan hormon kortisol. Gangguan yang diakibatkan dari hormon kortisol ini adalah terjadinya ketegangan pada otot. Ketegangan pada otot dapat berdampak kepada sakit di bagian punggung atau kepala yang terasa pusing. Selain itu, hormon kortisol yang tidak terkendali meningkatkan tekanan darah serta kadar glukosa darah, yang kemudian memicu diabetes. Penanganan hipertensi selain dengan perawatan farmakologi, juga dapat dilakukan dengan terapi psikologi. Terapi psikologi yang dimaksudkan ialah untuk membantu mengurangi tekanan darah, bukan menyembuhkan atau dengan kata lain sebagai pendukung terapi farmakologi (Muhdar, 2014).

Terdapat beberapa intervensi psikologi yang dapat digunakan dalam mengurangi kecemasan di antaranya adalah relaksasi, teknik grounding, teknik napas dalam, dan lain-lain. Selain itu, mengurangi kecemasan juga dapat dilakukan melalui intervensi kognitif, seperti mengidentifikasi dan mengubah pemikiran yang menyertai rasa cemas. Menurut pandangan kognitif, individu yang mengalami kecemasan memandang gangguan kecemasan disebabkan oleh proses-proses berpikir yang menyimpang. Individu yang mengalami kecemasan sering kali salah memersepsikan kejadian-kejadian biasa, seperti menyeberang jalan sebagai hal yang mengancam dan kognisinya terfokus pada antisipasi berbagai bencana pada masa mendatang (Manna, 
2019). Perhatian para individu yang mengalami kecemasan mudah terarah pada stimulus yang mengancam dan terpicu untuk menginterpretasi stimulus yang tidak jelas sebagai sesuatu yang mengancam. Sensitivitas individu yang mengalami kecemasan akan tetap tinggi, meskipun stimulus yang mengancam tidak dapat diterima secara.

Salah satu bentuk terapi psikologi dengan pendekatan kognitif, yaitu teknik self-talk, yang digunakan untuk menyangkal keyakinan irasional dan mengembangkan pemikiran yang lebih sehat, sehingga menghasilkan self-talk yang lebih positif. Seseorang dapat menggunakan dua macam selftalk, yaitu positive self-talk dan negative self-talk. Positive self-talk dapat membuat individu untuk tetap termotivasi dalam mencapai tujuan hidupnya, sedangkan negative self-talk sering kali bersifat selfdefeating dan mencegah individu untuk maju, sehingga individu didominasi oleh pesimisme dan kecemasan (Manna, 2019).

Positive self-talk merupakan proses memilih emosi positif dan menerapkannya pada persepsi dan keyakinan. Tujuannya untuk menciptakan cara pandang yang diterjemahkan ke dalam kenyataan yang baru dengan lebih baik. Positive self-talk diawali dengan sebuah keyakinan pada diri sendiri. Keyakinan bahwa dirinya mampu. Keyakinan yang mengatakan bahwa dirinya "bisa". Jika seseorang melihat dirinya "bisa", maka orang tersebut akan "bisa". Jika seseorang melihat dirinya akan berhasil, maka dirinya akan berhasil. Jika seseorang tidak bisa melakukan hal seperti ini, maka orang tersebut masih dikuasai oleh pikiran negatif (Permatasari, 2014).

Individu yang menerapkan berpikir positif dapat membantu dalam mengarahkan motivasi, kemampuan kognisi dan mengambil tindakan yang diperlukan untuk mencapai tujuan, dan mengatasi tantangan dengan optimal. Berpikir positif membuat individu cenderung berperasaan positif serta memandang tujuan hidup dapat diraihnya (Dwitantyanov, Hidayati, \& Sawitri, 2010). Seperti yang sudah dipaparkan di atas, ketika individu berpikir negatif terhadap suatu hal, otak akan mengolah hal-hal atau informasi yang negatif dan otak akan menggagalkan seluruh informasi positif yang lain. Maka dari itu, individu yang dapat menerapkan positive self-talk pada dirinya, berarti mampu memerintahkan otak untuk mengolah informasi yang positif, sehingga dapat menimbulkan perasaan yang positif juga. Dengan demikian, individu yang menerapkan positive self-talk, dapat mengurangi kecemasan dalam dirinya karena pikirannya tidak dipenuhi oleh ketakutan atau kekhawatiran yang irasional.

Berdasarkan berbagai pemaparan di atas, salah satunya yaitu penelitian dari Manna (2019) diketahui bahwa pendekatan kognitif dengan teknik self-talk telah terbukti efektif dalam mengurangi tingkat kecemasan lansia dengan hipertensi. Adapun tujuan dari penelitian ini adalah untuk mengetahui efektivitas intervensi positive self-talk dalam mengurangi tingkat kecemasan pada lansia dengan hipertensi.

\section{METODE}

Penelitian ini menggunakan metode eksperimen dengan desain re-treatment (one group pretest and posttest design). Metode ini digunakan untuk mengetahui kondisi partisipan sebelum dan sesudah diberikan perlakuan.

Pemilihan partisipan penelitian menggunakan teknik purposive sampling, di mana peneliti menentukan dalam pengambilan sampel dengan menentukan ciri-ciri khusus yang menjadi tujuan penelitian, yaitu lansia penderita hipertensi yang mengalami kecemasan. Jumlah partisipan yang diambil dalam penelitian ini adalah 8 perempuan lanjut usia berusia 66-79 tahun yang tinggal di RW VI Kelurahan Tegalpanggung Yogyakarta. Dalam prosesnya, terdapat sekitar 900 jiwa yang tinggal di RW ini, di mana jumlah laki-laki sekitar 400 jiwa, sedangkan jumlah perempuan sekitar 500 jiwa. Adapun lansia yang rutin mengikuti kontrol dan screening dari Puskesmas setempat sebanyak 30 lansia, yang didominasi oleh lansia perempuan. Sebenarnya masih banyak lansia di RW tersebut, namun beberapa lansia memilih tidak memeriksakan 
diri dan tidak melakukan screening karena berbagai alasan, antara lain kesibukan keluarga, takut bertemu pihak Puskesmas, malas, dan lain-lain. Berdasarkan screening yang dilakukan oleh pihak Puskesmas, dari 30 lansia, terdapat 10 lansia yang menunjukkan adanya indikasi kecemasan yang cukup berat. Hanya saja dalam prosesnya, satu lansia berjenis kelamin laki-laki dan satu lansia lainnya tidak mengikuti penelitian sampai selesai. Akhirnya, partisipan yang diambil sebanyak 8 lansia perempuan yang memenuhi kriteria yang dibutuhkan.

Penulis melakukan pengukuran di variabel kecemasan dengan menggunakan Hamilton Anxiety Rating Scale (HARS) untuk mengetahui skor pretest dan pos-ttest. HARS diperkenalkan oleh Max Hamilton tahun 1959 dan terdiri dari 14 aitem dengan 5 pilihan jawaban ( $0=$ "tidak ada", 1="ringan", 2="sedang", 3="berat", 4="berat sekali"). Adapun kategori kecemasan dalam HARS, yaitu: tidak ada kecemasan $(<14)$, ringan $(14-20)$, sedang (21-27), berat (28-41) dan berat sekali (4256). Perolehan skor partisipan didapat dengan cara menjumlahkan semua nilai yang dipilih oleh partisipan sesuai dengan kondisi yang dialami. Skor yang telah dijumlahkan oleh penulis kemudian dimasukkan sesuai kategori kecemasan dari HARS.

Penulis menggunakan HARS versi Bahasa Indonesia yang diadaptasi dari Uswandari (2017) Penulis juga tidak melakukan uji validitas dan uji reliabilitas, karena HARS sudah terstandar secara internasional dengan nilai validitas sebesar 0,93 dan nilai reliabilitas sebesar 0,97 (Norman dalam Uswandari, 2017). Selain itu, uji validitas dan reliabilitas versi Bahasa Indonesia juga telah dilakukan oleh Pramana, Okatiranti, dan Ningrum (2016) dengan nilai validitas 0,93 dan nilai reliabilitas 0,97 .

Penelitian ini dilakukan selama lima kali pertemuan, yakni dua kali dalam satu minggu dengan durasi 2 jam. Sebelumnya, penulis melakukan screening dengan pihak Puskesmas kepada lansia di RW tersebut. Penulis kemudian melakukan wawancara kepada lansia yang menunjukkan kecemasan. Lalu, penulis memberikan lembar pretest untuk mengetahui tingkat kecemasan yang dialami, lansia yang masuk dalam kategori kecemasan berat dipilih dalam kegiatan ini. Kemudian, partisipan diberikan informed consent sebagai tanda persetujuan dan kesediaannya mengikuti kegiatan ini sampai akhir. Dalam prosesnya, partisipan yang memenuhi kriteria dan bersedia mengikuti kegiatan adalah partisipan yang berjenis kelamin perempuan. Alasan para partisipan mengikuti kegiatan ini salah satunya adalah karena ingin merasa tenang dan tidak merasa cemas ketika dihadapkan pada stimulus yang mengancam dirinya.

Pada pertemuan pertama, partisipan diberikan teknik relaksasi pernapasan dan otot agar merasa nyaman dan tidak tegang saat self-disclosure di sesi Focussed Group Discussion (FGD) terkait masalah yang dihadapi. Relaksasi merupakan suatu teknik yang dapat membuat pikiran dan tubuh menjadi rileks (tidak tegang) melalui sebuah proses yang secara progresif dengan melepaskan ketegangan otot di setiap tubuh serta dengan melakukan pernapasan teratur. Adapun self-disclosure atau penyingkapan diri merupakan proses sharing atau sebuah proses membagikan informasi tentang diri sendiri kepada orang lain.

Kegiatan di pertemuan kedua yaitu penyampaian hasil asesmen, yakni hasil dari wawancara dan HARS. Hal ini bertujuan untuk menjelaskan hasil asesmen dan permasalahan yang dihadapi partisipan serta memberikan penjelasan mengenai bentuk intervensi yang akan diberikan kepada partisipan. Selanjutnya, partisipan diberikan psikoedukasi tentang hipertensi, kecemasan dan positive self-talk. Setelah partisipan paham mengenai kondisi yang dialami, partisipan diberikan dan dilatih terkait teknik positive self-talk di pertemuan selanjutnya, untuk membantu mengurangi kecemasan partisipan.

Pada pertemuan ketiga, partisipan diberi pelatihan positive self-talk pertama dengan tujuan membantu partisipan untuk mengubah pikiranpikiran irasional yang menyebabkan kecemasan. Adapun prosedurnya yaitu partisipan diberikan contoh dan penjelasan mengenai pengubahan negative selftalk menjadi positive self-talk. Selanjutnya partisipan 
diajak mengidentifikasi situasi yang memunculkan negative self-talk, reaksi emosi dan fisik yang dirasakan, kemudian diubah menjadi positive self-talk.

Pada pertemuan keempat, partisipan masih diberikan pelatihan positive self-talk kedua dengan tujuan membantu partisipan mengubah pernyataan diri yang salah dan negatif menjadi pernyataan diri yang lebih positif dan terarah. Adapun prosedurnya yaitu memberikan tugas kepada partisipan secara kelompok. Partisipan dibagi menjadi 3 kelompok. Dalam prosesnya, penulis memberikan ilustrasi situasi yang mengancam dan menimbulkan kecemasan bagi partisipan. Ilustrasi situasi tersebut merupakan kejadian sehari-hari yang cenderung negatif. Partisipan diminta untuk menentukan/ mencari positive self-talk untuk mencegah munculnya negative self-talk. Selanjutnya, partisipan diminta untuk mengidentifikasi adanya perubahan emosi yang dirasakan setelah mengubah negative self-talk menjadi positive self-talk.

Kegiatan di pertemuan kelima yaitu evaluasi, follow up dan posttest dengan tujuan untuk mengetahui perkembangan efektivitas intervensi yang telah diberikan kepada partisipan. Posttest yang diberikan kepada partisipan menggunakan HARS untuk mengukur tingkat kecemasan yang dialami partisipan setelah diberikan intervensi.

Tidak ketinggalan pula, di setiap pertemuan penulis juga mengukur tekanan darah partisipan menggunakan tensimeter sebelum dan sesudah pertemuan. Hal ini dilakukan untuk melihat perbedaan tekanan darah partisipan sebelum dan sesudah pertemuan. Sebelumnya, penulis telah mendapat pelatihan terkait pengukuran tekanan darah dari pihak Puskesmas setempat.

Adapun teknik analisis data yang digunakan untuk melihat perbedaan antara pretest dan posttest dalam kegiatan ini menggunakan uji statistic nonparametric Wilcoxon. Proses analisis data juga dilakukan dengan bantuan program Statistical Product and Service Solutions (SPSS) versi 22.

\section{HASIL}

Penelitian ini menunjukkan hasil bahwa pendekatan kognitif dengan teknik positive selftalk merupakan salah satu intervensi yang efektif untuk mengurangi kecemasan pada lansia penderita hipertensi. Teknik positive self-talk ini mengajak partisipan untuk mengidentifikasi situasi yang mengancam diri, pikiran negatif, perasaan dan respons fisik. Setelah partisipan memahami situasinya, partisipan kemudian diajak untuk mengubah pikiran negatif menjadi positif dengan cara berdialog dengan diri sendiri. Partisipan juga diminta untuk mempraktikkan hal tersebut dan merasakan perubahan yang dirasakan. Data yang disajikan pada tabel 1 merupakan tabel evaluasi kuantitatif yang memberikan gambaran perbandingan kondisi pretest dan posttest menggunakan HARS.

Tabel 1. Data pretest dan posttest partisipan

\begin{tabular}{cccccc}
\hline Nama & Pre test & Kategori & Post test & Kategori & Skor Turun \\
\hline SL (66) & 42 & Berat Sekali & 21 & Sedang & 21 \\
ST (67) & 37 & Berat Sekali & 17 & Sedang & 20 \\
P (74) & 40 & Berat Sekali & 21 & Sedang & 19 \\
TK (66) & 36 & Berat Sekali & 19 & Sedang & 17 \\
K (72) & 39 & Berat Sekali & 21 & Sedang & 18 \\
\hline
\end{tabular}

Tabel 2. Data pretest dan posttest partisipan (lanjutan)

\begin{tabular}{cccccc}
\hline Nama & Pre test & Kategori & Post test & Kategori & Skor Turun \\
\hline NS (75) & 43 & Berat Sekali & 22 & Sedang & 21 \\
SS (79) & 36 & Berat Sekali & 15 & Sedang & 21 \\
TG (66) & 41 & Berat Sekali & 23 & Sedang & 18 \\
\hline
\end{tabular}


Data di atas menunjukkan bahwa terjadi penurunan tingkat kecemasan yang dialami 8 partisipan. Kecemasan yang dialami partisipan sebelum diberikan intervensi berada pada kategori berat sekali dan setelah diberikan intervensi, kecemasan partisipan berada pada kategori sedang. Adapun penentuan kategori adalah dengan menjumlahkan nilai yang dipilih partisipan. Kemudian nilai tersebut dimasukkan sesuai dengan kategori HARS.

Tabel 2. Data Deskriptif Hasil Pengukuran Pretest dan Posttest

\begin{tabular}{lccccc}
\hline & N & Mean & SD & Minimum & Maximum \\
\hline Pre-test & 8 & 39.25 & 2.712 & 36 & 43 \\
Post-test & 8 & 19.88 & 2.696 & 15 & 23 \\
\hline
\end{tabular}

Penulis kemudian melakukan uji statistic non parametric Wilcoxon, yang menunjukkan nilai $\mathrm{Z}$ yang didapat sebesar -2,536 dengan $p$ value sebesar $0,011(\mathrm{p}<0,05)$. Artinya, ada perbedaan yang signifikan antara sebelum dan sesudah intervensi.
Skor rata-rata kecemasan sebelum diberikan intervensi ( $N=8 ; M=39,25 ; \mathrm{SD}=2,712)$ dan setelah diberikan intervensi terjadi $(\mathrm{N}=8 ; \quad \mathrm{M}=19,88$; $\mathrm{SD}=2,696)$ menunjukkan adanya penurunan. Data ini dapat dilihat pada Tabel 2 dan Tabel 3.

Tabel 3. Hasil Pengujian Wilcoxon Rank Test

\begin{tabular}{lc}
\hline & Post-test - Pre-test \\
\hline $\mathrm{Z}$ & -2.536 \\
Sig. (2-tailed) & .011 \\
\hline
\end{tabular}

\section{DISKUSI}

Hasil analisis data menunjukkan bahwa nilai $\mathrm{Z}=-2,536$ dengan $\mathrm{p}=0,011 \quad(\mathrm{p}<0,05)$. Hal ini menunjukkan bahwa terdapat perbedaan yang signifikan antara sebelum dan sesudah intervensi. Skor rata-rata kecemasan menunjukkan adanya penurunan dari sebelum diberikan intervensi $(M=39,25)$ dan di akhir intervensi $(M=19,88)$. Berdasarkan data tersebut, dapat diketahui bahwa terdapat yaitu adanya penurunan tingkat kecemasan sebelum dan sesudah pemberian positive self-talk.

Pikiran negatif yang dimiliki partisipan sering kali timbul karena adanya pengalaman yang kurang menyenangkan ketika dihadapkan pada situasi yang mengancam. Situasi mengancam bagi partisipan yaitu pada saat hendak memeriksakan kesehatan dan bertemu dokter. Pikiran otomatis negatif yang dimunculkan partisipan adalah nasib buruk akan menimpa dirinya, akan menderita penyakit penyerta lainnya serta ketakutan jika tekanan darah semakin tinggi. Pemikiran-pemikiran tersebut menimbulkan kecemasan pada partisipan sehingga aktivitas sehari-hari menjadi terganggu dan menimbulkan perasaan tidak nyaman.

Partisipan juga mengaku bahwa dirinya mengalami respons fisik seperti gemetar, jantung berdebar kencang, keringat dingin, pusing, sakit perut dan badan terasa kaku pada saat dihadapkan pada situasi yang mengancam dirinya. Kondisi ini ditambah dengan gejala-gejala yang dirasakan seperti perasaan takut, khawatir dan merasa diri tidak aman. Hal tersebut menyebabkan partisipan menghindari situasi yang mengancam dirinya, meskipun partisipan mampu menghadapi situasi tersebut, namun selalu diikuti perasaan tidak nyaman, khawatir, takut dan cemas.

Di sisi lain, tingginya tekanan darah partisipan disebabkan lupa jadwal periksa ke Puskesmas, adanya permasalahan terkait rumah tangga dan permasalahan ekonomi, serta lupa meminum obat. Partisipan menunjukkan adanya penurunan tekanan darah, dikarenakan partisipan merasa nyaman memiliki support group, merasa lebih tenang karena dapat berbagi cerita serta mengetahui teknikteknik dalam mengontrol pikiran negatif. 
Pada dasarnya ketakutan adalah respon rasional dalam situasi tertentu, akan tetapi beberapa orang merespon secara berlebihan terhadap objek, aktivitas atau situasi dengan membayangkan atau secara irasional melebih-lebihkan bahaya, sampai memunculkan rasa panik, ketakutan atau teror yang tidak sesuai dengan ancaman sebenarnya. Gangguan psikologis berupa perasaan takut, cemas dan gelisah disebabkan karena adanya keyakinan yang irasional pada diri seseorang. Kecemasan merupakan suatu ketegangan, rasa tidak aman, khawatir yang ditimbulkan karena dirasakan akan mengalami keadaan yang tidak menyenangkan (Nevid, 2005).

Gejala-gejala yang dirasakan partisipan, sesuai dengan kriteria diagnostik yang diungkapkan dalam PPDG (Maslim, 2008) yaitu: 1) kecemasan (khawatir akan nasib buruk, sulit konsentrasi, dsb), 2) Ketegangan motorik (gelisah, sakit kepala, gemetaran, tidak dapat santai) dan 3) Overaktivitas otonomik (kepala terasa ringan, berkeringat dingin, jantung berdebar-debar, sesak napas, keluhan lambung, pusing kepala, mulut kering, dsb).

Permasalahan yang dialami partisipan adalah adanya pikiran negatif yang otomatis muncul pada saat dihadapkan pada situasi mengancam. Pikiran negatif otomatis tersebut akhirnya mempengaruhi perasaan partisipan, kemudian memunculkan perasaan takut dan khawatir. Akhirnya partisipan menunjukkan respons fisik seperti, gemetar, pusing, jantung berdebar kencang, dll.

Pendekatan kognitif menjelaskan bahwa manusia memiliki potensi untuk menyerap pemikiran yang rasional dan irasional. Pemikiran yang irasional dapat mendorong timbulnya gangguan emosi dan perilaku. Pendekatan kognitif efektif untuk meningkatkan perilaku positif dan mengurangi pemikiran irasional yang menimbulkan perilaku yang tidak adaptif. Self-talk merupakan bentuk dari terapi kognitif atau bagian dari terapi kognitif yang mengubah pikiran irasional yang menyebabkan kecemasan, kesedihan, dan stres. Pendekatan ini akan mengubah pernyataan diri yang negatif dan salah menjadi lebih positif dan terarah (Martin \& Pear, 2015). Self-talk merupakan dialog di mana individu menafsirkan perasaan dan persepsi, mengatur dan mengubah evaluasi atau keyakinan, serta memberikan instruksi dan penguatan kepada diri sendiri (Permatasari, 2014). Self-talk merupakan cara kerja kognitif melalui proses mental yang berkontribusi dalam perubahan bentuk-bentuk pikiran (Wulandari, 2017).

Perkataan yang baik akan mempengaruhi keadaan hati dan pikiran. Apa pun yang dikatakan terhadap diri sendiri maka akan segera diafirmasi oleh otak yang kemudian mempengaruhi keadaan psikis. Self-talk yang positif akan menumbuhkan keyakinan (faith) pada diri seseorang. Oleh karena itu, individu sebaiknya harus jeli dalam pemilihan kata-kata untuk self-talk, apa yang diucapkan hendaknya yang bersifat positif dan mampu memberikan dorongan yang baik (Wulandari, 2017).

Positive self-talk juga mampu memunculkan emosi yang positif dengan cara memerintahkan dirinya sendiri untuk bersikap konstruktif (Permatasari, 2014). Sebaliknya, seseorang yang berpikir irasional dapat menyebabkan emosinya terganggu, yang dapat memunculkan depresi, merasa rendah diri, menyalahkan diri sendiri dan khawatir. Kedua jenis self-talk tersebut dapat dipengaruhi oleh keadaan diri seseorang dalam menyikapi sesuatu. Hal ini dapat memersepsi pikiran seseorang dalam keadaan positif maupun negatif (Wulandari, 2017).

Menurut Corey (2009), untuk mencapai tujuan sesungguhnya dari positive self-talk, ada beberapa tahap yang harus dilakukan, yaitu individu ditunjukkan bahwa permasalahan yang dihadapi berkaitan dengan keyakinan-keyakinan irasional yang ada pada dirinya. Bisa dikatakan bahwa pada tahap ini individu belajar untuk memisahkan keyakinan-keyakinan rasional dan keyakinan irasional. Selanjutnya, individu dibawa pada kesadaran bahwa individu hanya mempertahankan gangguan-gangguan emosionalnya untuk tetap aktif dengan terus menerus berpikir secara irasional dan mengulang-ulang kalimat atau perkataan yang mengalahkan diri. Kemudian, individu diajarkan untuk memperbaiki dan meninggalkan pikiran serta 
gagasan irasional yang dimiliki. Maksudnya, individu diajak untuk mengubah pikiran dan pernyataan negatifnya menjadi pikiran dan pernyataan yang positif. Adapun yang terakhir, individu diminta untuk mengembangkan filosofi kehidupannya yang rasional. Cara yang digunakan dengan menolak kehidupan yang irasional dan menolak pikiran-pikiran irasional dan pernyataanpernyataan negatif untuk masuk kepada diri sendiri.

Hasil dari kegiatan ini juga didukung oleh penelitian terdahulu yang dilakukan oleh Masithoh, Himawan \& Hidayah (2016) dengan judul penelitian terapi berpikir positif dan tekanan darah pada pasien hipertensi. Partisipan dalam penelitian tersebut sebanyak 30 penderita hipertensi, baik laki-laki maupun perempuan dengan rentang usia 36-55 tahun. Hasil penelitian tersebut menunjukkan bahwa ada pengaruh terapi berpikir positif terhadap tekanan darah pada pasien hipertensi di Puskesmas Welahan I Kabupaten Jepara, dibuktikan dengan $p$ value $=0,000(\mathrm{p}<0,05)$.

Tingkat kecemasan yang dialami oleh masingmasing partisipan dalam kegiatan ini masuk kategori yang sama. Dalam pelaksanaannya, partisipan menunjukkan adanya kemajuan sehingga proses intervensi berjalan dengan baik. Berbagai sumber kecemasan dapat menyebabkan partisipan mendapatkan insight dengan cepat dari cerita yang berbeda, hal ini menjadikan antar partisipan menyadari bahwa bukan hanya dirinya yang mengalami masalah. Salah satunya subjek SS yang mengalami penurunan tingkat kecemasan sebanyak 21 poin. Para partisipan diminta untuk mempertahankan perubahan agar kondisi fisik dan psikologis menjadi lebih baik. Partisipan lain juga tampak memberikan semangat pada SS dan merasa termotivasi untuk terus melanjutkan intervensi yang telah diberikan. SS juga mengakui bahwa saat ini dirinya merasa lebih baik, bahagia dalam menjalani hari-hari dan lebih bersemangat. Partisipan menunjukkan penurunan tingkat kecemasan dan tekanan darah yang cukup signifikan, hal ini karena partisipan rutin mempraktikkan intervensi yang telah diberikan.
Proses intervensi dalam kegiatan ini telah membawa partisipan untuk saling belajar dari permasalahan sesama partisipan. Secara tidak langsung, partisipan juga membandingkan masalah yang dialami dengan partisipan lain untuk mengoreksi penilaian terhadap dirinya sendiri dan reaksi terhadap masalah yang dihadapi. Rangkaian tersebut secara perlahan dan disadari telah meningkatkan kemampuan interaksi sosial antar partisipan dan menurunkan tingkat kecemasan dalam berinteraksi dengan orang lain serta mendiskualifikasi keluhan-keluhan fisik karena cemas.

Adapun manfaat dari penelitian ini adalah selain terbentuknya support system antar peserta kelompok, juga memberikan pemahaman bahwa pikiran yang irrasional dapat memberikan dampak yang negatif pada diri individu. Hal ini karena pikiran mampu mempengaruhi perilaku dan perasaan, sehingga output yang dikeluarkan nantinya sesuai dengan apa yang dipikirkan oleh individu.

Tidak dapat dipungkiri, penelitian ini juga mengalami beberapa kelemahan, antara lain (1) Latar belakang pendidikan partisipan yang tidak bisa menulis, membaca dan karena kondisi fisik yang tidak memungkinkan untuk menulis. Akhirnya worksheet/lembar kerja partisipan selama pelatihan positive self-talk dicatat oleh penulis sesuai dengan ucapan dan ungkapan dari masing-masing partisipan; (2) Keterbatasan tim dalam kegiatan ini, membuat penulis melakukan kegiatan ini secara individu; (3) Terdapat beberapa partisipan yang mengalami permasalahan eksternal, sehingga ketika mengikuti sesi intervensi, tekanan darah partisipan menjadi tinggi dan kecemasan yang dialami partisipan meningkat. Selain itu, faktor eksternal berupa perasaan bahagia yang dialami salah satu partisipan juga mempengaruhi kecemasan yang dialami, sehingga kecemasannya menjadi berkurang. Partisipan diharapkan untuk rutin meminum obat selama mengikuti kegiatan, namun hal tersebut tidak dikontrol oleh penulis.

Adapun saran dari penelitian ini yaitu, peneliti selanjutnya diharapkan dapat mengembangkan penelitian serupa dengan menambahkan teknik- 
teknik lain dalam pendekatan kognitif serta memperbanyak partisipan sehingga hasilnya dapat digeneralisasikan pada populasi yang lebih luas. Kepada para ilmuwan, psikolog dan praktisi psikologi di bidang klinis, dapat melakukan psikoedukasi kepada masyarakat terkait pikiran, emosi dan perilaku pada orang-orang yang mengalami kecemasan, sehingga hasil penelitian yang dilakukan dapat memberikan sumbangan secara nyata bagi permasalahan yang terjadi dalam masyarakat. Kepada partisipan, diharapkan mampu mengurangi kecemasan dengan mengontrol pikiran negatif dengan cara mempraktikkan intervensi yang telah diberikan.

\section{SIMPULAN}

Pendekatan kognitif dengan melakukan pelatihan positive self-talk terbukti efektif dalam mengurangi gejala-gejala kecemasan orang lanjut usia penderita hipertensi. Partisipan menunjukkan penurunan tingkat kecemasan yang signifikan sebelum dan sesudah intervensi, dibuktikan dengan hasil perhitungan Wilcoxon Signed Rank Test, diketahui nilai $\mathrm{Z}=-2,536$ dengan signifikansi $\mathrm{p}=0,011 \quad(\mathrm{p}<0,05)$. Artinya, ada perbedaan yang signifikan antara tingkat kecemasan yang dialami partisipan sebelum dan sesudah proses intervensi. Kecemasan yang dialami partisipan masuk dalam kategori sedang setelah diberikan intervensi. Individu yang mampu melakukan positive self-talk akan memunculkan emosi yang positif, sehingga mampu membangun semangat sendiri untuk mencapai perubahan yang diinginkan. Individu yang berada dalam kondisi ini akan diliputi emosi positif, sehingga emosinya tidak terganggu karena dipengaruhi oleh pikiran yang irasional.

\section{DAFTAR PUSTAKA}

Badan Pusat Statistik. (2020). Statistik penduduk lansia. Jakarta: Badan Pusat Statistik.

Brunner, \& Suddarth. (2013). Buku ajar keperawatan medikal bedah edisi 8 volume 2. Jakarta: EGC.

Dwitantyanov, A., Hidayati, F., \& Sawitri, D. R. (2010). Pengaruh pelatihan berpikir positif pada efikasi diri akademik mahasiswa (Studi eksperimen pada mahasiswa Fakultas Psikologi UNDIP Semarang). Jurnal Psikologi UNDIP, 8(2), 135-144.

Girsang, D. (2013). Hipertensi. Dipetik Maret 18, 2020,http://kardioipdrscm.com/5891/beritadan-informasi/hari-kesehatandunia-2013kampanye-papdi-melawan-hipertensi

Hurlock, E. B. (2012). Psikologi perkembangan: Suatu perkembangan sepanjang rentang kehidupan. Jakarta: Erlangga.

Imelda, Sjaaf,F., \& Puspita. (2020). Faktor-faktor yang berhubungan dengan kejadian hipertensi pada lansia di Puskesmas Air Dingin Lubuk Minturun. Health \& Medical Journal, 2(2), 68-77.

Kaplan, \& Sadock, B. J. (2010). Buku ajar psikiatri klinis. Edisi II. Jakarta: EGC.

Manna, M. (2019). Teknik self talk untuk mengurangi kecemasan pada lansia dengan gangguan cemas menyeluruh. Prosiding Seminar Nasional \& Call Paper Psikologi Sosial 2019 (hal. 117-121). Surabaya: Fakultas Pendidikan Psikologi Universitas 17 Agustus 1945.

Maramis, R. I. (2016). Kebermaknaan hidup dan kecemasan dalam menghadapi kematian pada lansia di panti wedha Samarinda. Ejournal Psikologi, 319-332.

Martin, G., \& Pear, J. (2015). Behavior modification: What it is and how do it. New Jersey, USA: Pearson Education, INC.

Masithoh, A.R, Himawan, R., \& Hidayah, N. (2016). Terapi berpikir positif dan tekanan darah pada pasien hipertensi. Jurnal Ilmu Keperawatan dan Kebidanan, 7(2), 23-26.

Maslim, R. (2008). Buku Saku Diagnosis Gangguan Jiwa: Rujukan Ringkas dari PPDGJ - III. Jakarta: FK Unika Atmajaya.

Muhdar. (2014). Pengaruh pemberian teknik relaksasi progresif terhadap perubahan tekanan darah pada lansia penderita hipertensi di Panti Sosial Tresna Werdha (PSTW) Yogyakarta unit Budi Luhur Kasongan Bantul. Yogyakarta: STIKES 'Aisyiyah. 
Nevid, J. S. (2005). Psikologi abnormal. Jakarta: Erlangga.

Permatasari, Y. S. (2014). Efektivitas Pelatihan Self-talk Untuk Meningkatkan Efikasi Diri dan Penampilan Atlet Kumite Karate UNS. Skripsi. Universitas Sebelas Maret. Surakarta.

Pramana, K. D., Okatiranti, \& Ningrum, T. P. (2016). Hubungan tingkat kecemasan dengan kejadian hipertensi di panti sosial Tresna Werdha Senjarawi Bandung. Jurnal Ilmu Keperawatan, 4(2), 116-128.

Ridwan, Widodo, D., \& Widiani, E. (2017). Hubungan hipertensi dengan kecemasan pada lanjut usia di POSYANDU Permadi Kelurahan Tlogomas Kecamatan Lowokwaru Kota Malang. Nursing News, 2(3), 676-686.

Riset Kesehatan Dasar. (2018). Badan penelitian dan pengembangan kesehatan. Jakarta: Batlibankes.

Santrock, J.W. (2012). Perkembangan Masa Hidup Edisi 13 Jilid 1 (terjemahan). Jakarta: Erlangga.
Sari, N. W., Margiyati, \& Rahmanti, A. (2020). Efektivitas metode self help group (SHG) terhadap tekanan darah pada lansia hipertensi. Jurnal Keperawatan, 3(3), 10-16.

Sundeen, \& Stuart. (2015). Buku saku keperawatan jiwa. Jakarta: EGC.

Uswandari, B. D. (2017). Hubungan antara kecemasan dengan kejadian hipertensi pada lansia di panti sosial Tresna Werdha. Surakarta: Fakultas Psikologi Universitas Muhammadiyah Surakarta.

Wulandari, C. T. (2017). Self-talk untuk mencapai penerimaan diri pada penyandang disabilitas netra di rumah pelayanan sosial disabilitas netra "BHAKTI CANDRASA" Surakarta. Skripsi. Institut Agama Islam Negeri. Surakarta.

Naskah masuk : 22 April 2021

Naskah diterima: 13 Desember 2021 